\title{
腎細胞癌脳転移の臨床的背景と治療
}

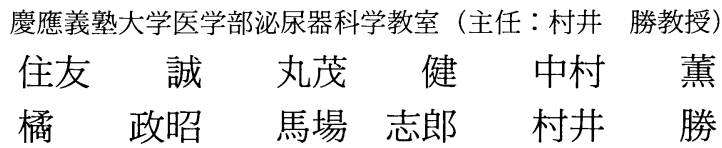

\section{CLINICAL BACKGROUND AND TREATMENT OF BRAIN METASTASIS FROM RENAL CELL CARCINOMA}

\author{
Makoto Sumitomo, Ken Marumo, Kaoru Nakamura, Masaaki Tachibana, \\ Shiro Baba and Masaru Murai \\ Department of Urology, School of Medicine, Keio University \\ (Director: Prof. Masaru Murai)
}

(Objective) The objective of this study is to evaluate the clinicopathological characteristics and the effect of therapy of brain metastasis from renal cell carcinoma.

(Method) Of 306 cases with renal cell carcinoma treated at Keio University Hospital from June, 1976 to May, 1996, 20 (6.5\%) developed brain metastasis. Metastasis-free rate and survival rate were evaluated by Kaplan-Meier's method and tested statistically with Long-rank test.

(Result) As for the time of the brain metastasis, it was already at the time of initial diagnosis in 6 cases, and in the other 14, it was after the diagnosis of original disease. The average interval between the diagnosis of original disease and metastasis was 53.9 months. Only 2 cases have no metastasis without brain, and 17 of 20 cases $(85.0 \%)$ were complicated by pulmonary metastasis and $10(50.0 \%)$ by bone metastasis. It was considered that the brain metastasis was accompanied with other metastases. As for the treatment, cytokine therapy was performed on 18 cases without efficasy. It was supposed that in cases with pulmonary metastasis, IL-2 therapy may have the possibility of increasing the frequency of brain metastasis. 9 of 20 cases were subjected to surgical treatment with significantly better prognosis than the cases without the operation. Two cases were long-term survivors more than 5 years after the diagnosis of brain metastasis and both underwent surgical treatment to brain metastasis.

(Conclusion) Cytokine therapy was not effective to brain metastasis from renal cell carcinoma. On the other hand, however, it was suggested that surgical treatment could improve prognosis if the metastatic lesions could be resected.

Key words: renal cell carcinoma, brain metastasis, surgical treatment

要旨：(目的)腎細胞癌脳転移症例の臨床病理学的特徴および治療効果の検討を行った。

（方法）1976年 6 月より1996年 5 月までの 20 年間に慶応義塾大学病院を受診し，長期に経過観察した 腎細胞癌306例中，脳転移を認めた20例 (6.5\%) を対象とした。転移出現率，生存率は Kaplan-Meier 法 を用いて算出し, log-rank 法を用いて有意差検定を行った。

（結果）脳転移が診断された時期に関しては，初診時すでに脳転移が認められたものが 6 例で，他の 14例は原発巣の病理学的診断後に診断されており, 脳転移出現までの期間は平均53.9力月で，転移まで に長期間を要する傾向が認められた，脳への単独転移は 2 例のみで，20例中17例（85.\%）が肺転移を， また 10 例 $(50.0 \%)$ が骨転移を合併しており, 腎細胞癌の脳転移は他臟器転移を伴う傾向が認められた。 治療法として，免疫療法は18例に施行されたが，単独で転移巣の縮小を認めた例はなかったまた，肺 転移症例において, Interleukin-2には脳転移出現を惹起する可能性があることが示唆された.手術療法は 
20 例中 9 例に施行されたが，手術群は非手術群より予後良好である傾向がみられ，脳転移後 5 年以上生 存した症例は 2 例のみであったが， 2 例とも脳転移巣の外科的切除を施行されていた.

（結論）腎細胞癌脳転移症例においては，免疫療法による治療効果には限界がある一方，転移巣が摘 除可能であれば，外科的治療を施行することにより，予後の改善が得られる可能性があることが示唆さ れた。

キーワード：腎細胞癌，脳転移，外科的切除

\section{緒 言}

腎細胞癌の脳転移は，臨床的には $5 \sim 10 \%$ の頻度で

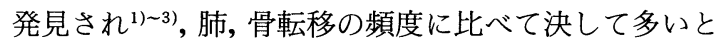
はいえないが，剖検時には約10\%の患者に認めら $れ^{233)}$, 泌尿器科癌では最も頻度が高い。また, その臓 器特異性から考えて，嘔気，麻痺などの臨床症状を伴 いやすく，患者の生活の質（Quality of life）を著しく 悪化させることになる。一方で，脳転移の他臓器転移 との関係や外科的手術，免疫療法などの治療効果につ いての臨床的な検討の報告は少なく，治療方針の選択 についても曖昧な点が多いのが現状である。われわれ は, 腎細胞癌の脳転移の臨床病理学的特徵について, 原発巣抢よび他臟器転移との関係から検討し，また， 脳転移巣の外科的手術療法を中心に治療効果の検討を 行ったので報告する。

\section{対象および方法}

1976年 6 月より1996年 5 月までの 20 年間に慶應義塾 大学病院を受診した腎細胞癌306例中,脳転移を認めた 20例 (6.5\%) を対象とした。性別は男性14例，女性 6 例であった. 年齢は37歳から 75 歳で, 平均 57.1 歳であっ た。脳転移は CT スキャン, MRI の所見から診断し, 脳原発または他の悪性腫瘍の転移の可能性があるもの を除外した。脳転移巣の手術適応は原則的に単発性で 切除可能なものとし, 脳転移巣手術症例は全例腫瘍核 出術を施行された。転移出現率，生存率は KaplanMeier 法を用いて算出し, log-rank 法を用いて有意差 検定を行い,危険率 $5 \%$ 以下を有意差ありと判定した。 また， 2 群間の比較には $\chi^{2}$ 検定を用いた。病期分類は 腎癌取扱い規約 (第 2 版 $)^{4}$ に従い, PS には小出・斎藤 班の 5 段階分類を用いた。

\section{結果}

1. 原発巣の患側

原発巣の患側に関しては，右腎が13例（全右側症例 165例の7.9\%), 左腎が 6 例（全左側症例137例の $4.4 \%$ ), 両側が 1 例（全両側症例 4 例）であり，右側 が脳転移を生じる頻度が高い傾向が認められたが，有 意差を認めなかった。

\section{2. 原発巣に対する手術}

20例中16例に対し根治的腎摘除術，1例に両腎部分 切除術が施行された。他の 3 例については, 発見時, すでに多臓器転移を合併しており，確定診断のために 針生検が施行された。

3. 原発巣の病理学的所見

原発巣の腫崵径は最小 $35 \mathrm{~mm}$ から最大 $120 \mathrm{~mm}$ で平 均 $73.3 \mathrm{~mm}$ であった. 組織学的構築型では胞巣型が 17 例，腺管型が 2 例，充実型が 1 例であった。細胞型は 通常型の淡明細胞亜型が17例, 顆粒細胞亜型が 1 例, 紡鍾細胞型が 1 例，混合型が 1 例であった。病理学的 病期については pT2が12例, pT3a が 5 例, pT 3b が 2 例, pT4が 1 例であり, 14例中 pT1は 1 例も認めなかっ た. 異型度では G1が 3 例, G2が12例, G3が 4 例であっ た. INF に関しては $\alpha$ が 4 例, $\beta$ が12例, $\gamma$ が 4 例で あった (表 1 ). high grade, high stage のものに脳転 移が生じやすい傾向が認められたが，脳以外の遠隔転 移を生じた群と比較し, 有意差は認められなかった。

\section{4. 脳転移の診断時期}

脳転移が診断された時期に関しては，初診時すでに 脳転移が認められたものが 6 例で, 残りの14例は原発 巣の診断後に脳転移が認められており，その期間は最 短 2 力月から最長 169 力月で，平均53.9力月であった (表 2 ).

\section{5. 脳転移の部位}

脳転移巣の数については, 単発性が13例, 多発性が 7 例であり, 単発性の占拠部位は, 側頭葉が 5 例, 頭 頂葉が 3 例, 前頭葉が 3 例, 頭頂葉から側頭葉が 1 例, 側頭葉から後頭葉が 1 例であり, 中大脳動脈支配領域 が圧倒的に多く, 多発例を含めても, 小脳転移は認め なかった（表 2 )。

6. 脳転移による主症状

脳転移による主症状としては, 麻瘴が 7 例, 嘔気が 5 例, 痙攣が 4 例, 頭痛が 2 例, 意識障害が 1 例であ り，1例は偶然発見された（表 2 )。

7. 他藏器転移との関係

遠隔転移を認めた腎細胞癌症例は73例であり, 脳転 
表 1 症例の背景と原発巣の病理組織学的所見

\begin{tabular}{|c|c|c|c|c|c|c|c|c|c|c|c|c|c|c|}
\hline 症例 & 年齢 & 性 & 患側 & 手術 & 構築型 & 紐胞型 & $\begin{array}{l}\text { 腫瘍径 } \\
\text { (mm) }\end{array}$ & $\mathrm{pT}$ & Gr & INF & $\mathrm{pV}$ & $\mathrm{pN}$ & M & 脳以外転移藏器 \\
\hline 1 & 58 & 男 & 左 & 腎摘 & 腺管 & 淡明 & 80 & 2 & 2 & 2 & 0 & 0 & 0 & 肺，骨 \\
\hline 2 & 56 & 男 & 右 & 腎摘 & 胞巣 & 淡明 & 45 & 2 & 2 & 3 & 0 & 0 & 0 & 肺，骨 \\
\hline 3 & 71 & 女 & 左 & 腎摘 & 胞巣 & 淡明 & 65 & $3 a$ & 3 & 3 & 0 & 2 & 1 & 肺, 甲状腺 \\
\hline 4 & 49 & 女 & 右 & 生検 & 胞巣 & 淡明 & 120 & 4 & 3 & 3 & 0 & 2 & 1 & 肺, 骨, 肝 \\
\hline 5 & 54 & 男 & 左 & 腎摘 & 胞巣 & 淡明 & 35 & $3 \mathrm{~b}$ & 2 & 1 & 0 & 0 & 1 & 肺，右腎 \\
\hline 6 & 62 & 男 & 両側 & 部切 & 胞単 & 淡明 & 100 & $3 a$ & 2 & 2 & 0 & 0 & 1 & 肺 \\
\hline 7 & 53 & 女 & 右 & 腎摘 & 胞巣 & 淡明 & 45 & 2 & 2 & 2 & 0 & 0 & 1 & 肺 \\
\hline 8 & 75 & 男 & 右 & 腎摘 & 胞巣 & 混合 & 80 & 2 & 3 & 2 & 2 & 2 & 1 & 肺，骨 \\
\hline 9 & 70 & 男 & 右 & 腎摘 & 胞巣 & 淡明 & 60 & 2 & 2 & 2 & 0 & 0 & 1 & 肺 \\
\hline 10 & 57 & 女 & 右 & 腎摘 & 胞巣 & 淡明 & 60 & 2 & 2 & 2 & 0 & 1 & 0 & 肺，骨 \\
\hline 11 & 45 & 男 & 左 & 腎摘 & 胞巣 & 淡明 & 60 & 2 & 1 & 2 & 0 & 0 & 0 & 肺, 骨, 肝 \\
\hline 12 & 62 & 男 & 左 & 生検 & 胞巣 & 淡明 & 90 & $3 a$ & 1 & 2 & 0 & 0 & 1 & 肺，骨 \\
\hline 13 & 56 & 男 & 左 & 腎摘 & 充実 & 紡鍾 & 100 & $3 a$ & 3 & 3 & 0 & 0 & 1 & 肺，骨 \\
\hline 14 & 59 & 女 & 右 & 腎摘 & 胞巣 & 淡明 & 85 & $3 a$ & 2 & 2 & $1 \mathrm{~b}$ & 0 & 1 & 肺，骨，膵 \\
\hline 15 & 58 & 男 & 右 & 生検 & 胞巣 & 淡明 & 55 & 2 & 2 & 2 & 0 & 0 & 1 & 肺 \\
\hline 16 & 56 & 男 & 右 & 腎摘 & 胞巣 & 顆粒 & 50 & 2 & 1 & 2 & 0 & 0 & 0 & 肺 \\
\hline 17 & 57 & 男 & 右 & 腎摘 & 胞単 & 淡明 & 120 & $3 a$ & 2 & 1 & 0 & 0 & 0 & 肺，骨 \\
\hline 18 & 53 & 女 & 右 & 腎摘 & 腺管 & 淡明 & 65 & 2 & 2 & 2 & 0 & 1 & 1 & なし \\
\hline 19 & 53 & 男 & 左 & 腎摘 & 胞巣 & 淡明 & 60 & 2 & 2 & 1 & 0 & 0 & 0 & 右腎 \\
\hline 20 & 37 & 男 & 右 & 腎摘 & 胞単 & 淡明 & 90 & 2 & 2 & 1 & 0 & 0 & 0 & なし \\
\hline
\end{tabular}

表 2 脳転移の臨床所見と治療

\begin{tabular}{|c|c|c|c|c|c|c|c|c|}
\hline 症例 & 初診時脳転移 & \begin{tabular}{|c} 
原発巣診断から脳転移 \\
帘の゙期間 $)$
\end{tabular} & 脳転移部位 & 主訴 & PS & 脳転移巣手術 & 兔疫療法 & $\begin{array}{l}\text { 脳転移から死亡 } \\
\text { までの期間(月) }\end{array}$ \\
\hline 1 & 無 & 73 & 側頭葉 & 嘔気 & 2 & 施行せず & IFN- $\alpha$ & 21 \\
\hline 2 & 無 & 169 & 頭頂葉 & 嘔気 & 3 & 施行せず & 施行せず & 2 \\
\hline 3 & 無 & 110 & 多発 & 麻痺 & 3 & 施行せず & IFN- $\alpha$ & 6 \\
\hline 4 & 有 & 0 & 多発 & 頭痛 & 4 & 施行せず & IL2 & 1 \\
\hline 5 & 無 & 68 & 多発 & 麻疸 & 3 & 施行せず & IFN- $\alpha$ & 2 \\
\hline 6 & 無 & 82 & 側頭葉 & 麻瘒 & 4 & 施行 ( 2 回) & IL2 & 22 \\
\hline 7 & 無 & 7 & 側頭葉～後頭葉 & 痗攣 & 3 & 施行 ( 2 回) & IL2 & 16 \\
\hline 8 & 有 & 0 & 多発 & 麻痺 & 4 & 施行せず & IL2 & 1 \\
\hline 9 & 有 & 0 & 前頭葉 & 偶発性 & 1 & 施行 & IL2 & 16 \\
\hline 10 & 無 & 3 & 側頭葉 & 麻㾝 & 3 & 施行せず & IFN $-\alpha$ & 10 \\
\hline 11 & 無 & 60 & 多発 & 哣気 & 3 & 施行せず & IFN- $\alpha$ & 3(生存) \\
\hline 12 & 有 & 0 & 多発 & 痙攣 & 3 & 施行せず & IL2 & 2 \\
\hline 13 & 有 & 0 & 多発 & 嘔気 & 3 & 施行せず & IL2 & 1 \\
\hline 14 & 無 & 9 & 頭頂葉 & 麻痺 & 3 & 施行せず & IFN- $\alpha$ & 12 \\
\hline 15 & 無 & 2 & 頭頂葉～側頭葉 & 意識障害 & 4 & 施行 & 施行せず & 0 \\
\hline 16 & 無 & 50 & 側頭葉 & 㾞攣 & 3 & 施行 (3回) & IL2 & 28 \\
\hline 17 & 無 & 75 & 頭頂葉 & 頭痛 & 4 & 施行 (2回) & IL2 & 14 \\
\hline 18 & 有 & 0 & 前頭葉 & 嘔気 & 3 & 施行 & IFN- $\alpha$ & 62 \\
\hline 19 & 無 & 31 & 前頭葉 & 麻痺 & 3 & 施行 & IFN- $\alpha$ & 125 (生存) \\
\hline 20 & 無 & 69 & 側頭葉 & 痙攣 & 4 & 施行 & IFN- $\alpha$ & 34 \\
\hline
\end{tabular}


図 1 肺転移の有無と脳転移出現率との関係

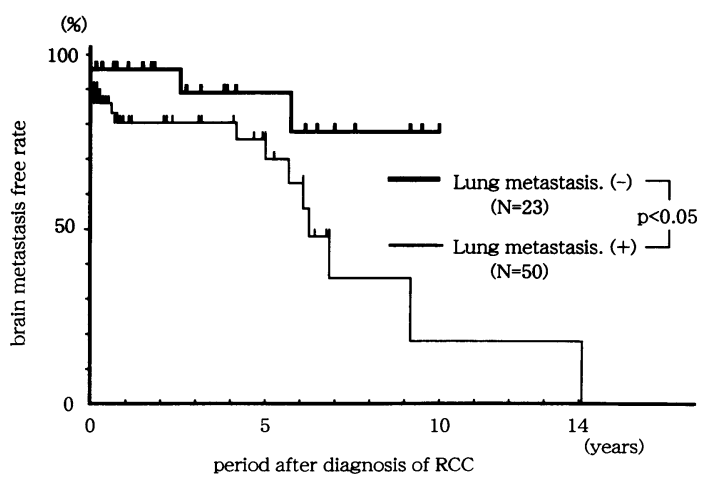

移症例はそのうち $27.4 \%$ 頻度で出現した。脳への単 独転移は 2 例のみで，20例中17例（85.0\%）が肺転移 を合併し，肺転移症例50例中の34.0\%を占めた。遠隔 転移を認めた腎細胞癌症例において，肺転移を認めた 群と肺転移を認めない群とでは, 脳転移出現率に関し て有意差が認められた $(\mathrm{p}<0.05)$ （図 1 )。また，17例 中10例は肺転移の後で脳転移が認められており, 腎細 胞癌の脳転移は肺転移に引き続いて生じる傾向が認め られた。また，脳転移が肺転移に先行した症例は認め なかった，一方，脳転移を合併した肺転移症例群の生 存率と, 脳転移を合併していない肺転移症例群の生存 率とでは，予後に有意な差を認めなかった(図 2 )。骨 転移の合併は脳転移症例中10例（50.0\%）であり，骨 転移症例24例中の $41.7 \%$ 占めた，骨転移を認めた群 は認めない群と比較し, 脳転移を合併しやすい傾向が 認められたが，有意差は認められなかった（図 3 ).

8. 肺転移に対する免疫療法と脳転移との関係

肺転移を生じた腎細胞癌症例 50 例のうち, 肺転移巣 の手術または放射線療法を施行せずに，免疫療法を中 心とした補助療法を施行した 36 症例について, その治 療効果および脳転移の出現率について検討した。 36症 例のうち, Interferon- $\alpha$ (IFN- $\alpha$ ) 治療群は15例, Interleukin-2 (IL-2) 治療群は10例, 他治療群は11例で あり， 3 群において，年歯のばらつきは認めなかった が, PS については, IFN- $\alpha$ 治療群, IL-2治療群, 他治 療群の中央值はそれぞれ $1.9,1.8,2.4 て ゙ あ り$, 有意差 は認めなかったが, 他治療群の PS が高い傾向が認め られた.肺転移巣に対する治療効果については, IFN- $\alpha$ 治療群で著効 (CR) 1 例, 有効 (PR) 2 例, 不変 (NC) 7 例, 進行 (PD) 5 例, IL-2治療群で CR 1 例, PR 1 例, NC 5 例, PD 3 例, 他治療群で CR 1 例, PR 0
図 2 脳転移の有無による肺転移症例の予後の関係

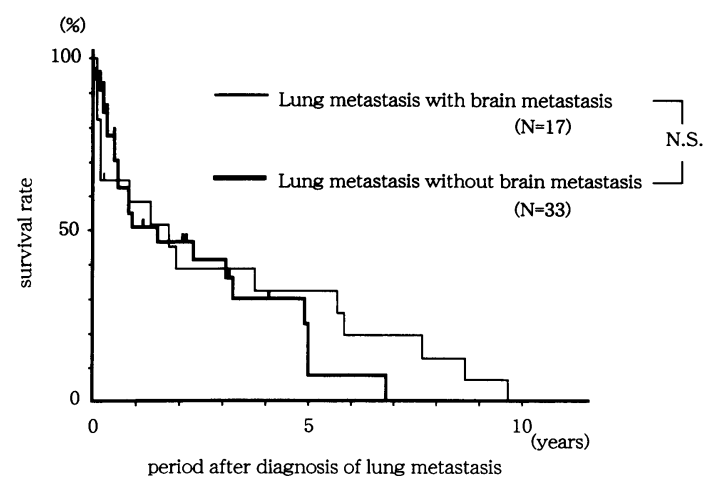

図 3 骨転移の有無と脳転移出現率との関係

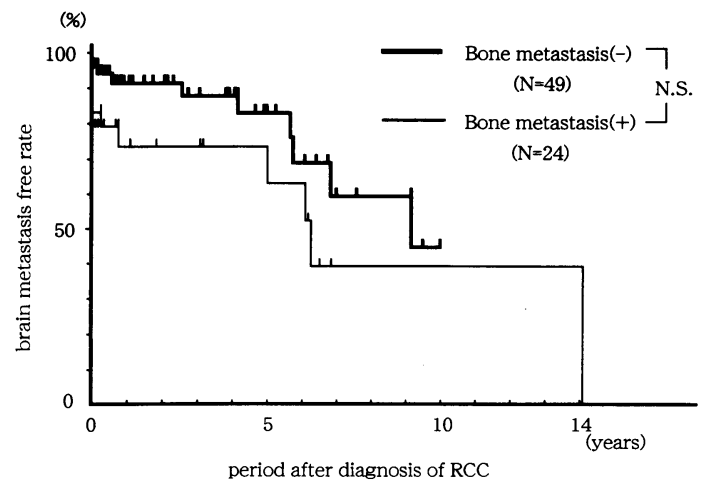

例, NC 5 例, PD 4 例であり, 奏効率はそれぞれ $20.0 \% ， 20.0 \% ， 9.1 \%$ であった．脳転移は IFN- $\alpha$ 治 療群で15例中 2 例 (13.3\%), IL-2治療群で10例中 4 例 (40.0\%)，他治療群で11例中 2 例（18.2\%）に認めら れた. IL-2治療群と他治療群の間には,脳転移出現率に 関して有意差が認められた $(\mathrm{p}<0.05)$. IL-2治療群と IFN- $\alpha$ 治療群との間には, 有意差は認められなかった が, IL-2治療群の方が比較的早期に脳転移が出現する 傾向が認められた。一方, IFN - $\alpha$ 治療群と他治療群と の間には有意差が認められなかった（図 4 ).

9. 脳転移に対する治療法と予後との関係

全症例の脳転移診断後の 1 年生存率は $48.8 \%, 5$ 年 生存率は $16.2 \%$ であり, 全体としての予後は不良で あった. 20 例中 9 例に脳転移巣の手術を施行したが, 手術群の 1 年生存率は $88.9 \%, 5$ 年生存率は $33.3 \%$ と 予後の改善が得られた。一方, 非手術群の 1 年生存率 は $11.4 \%, 5$ 年生存率は $0 \%$ であり, 両群の生存率に は有意差が認められた $(\mathrm{p}<0.05)$ （図 5 )。ただし, 手 
図 4 肺転移に対する免疫療法と脳転移出現率との関 係

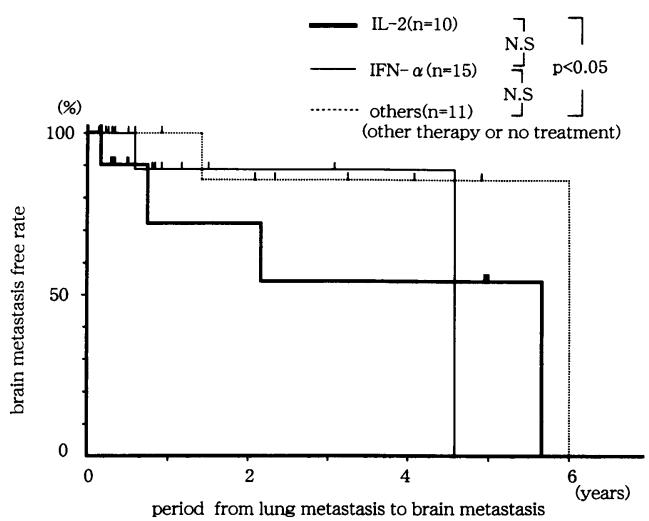

図 5 脳転移に対する手術療法と予後との関係

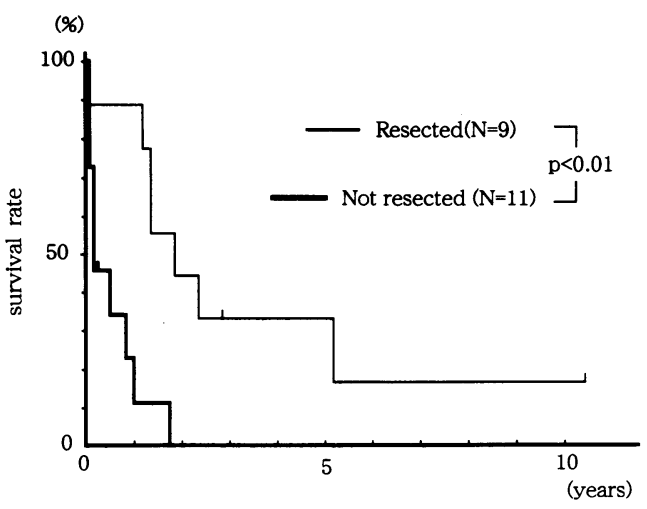

period after diagnosis of brain metastasis

術群と非手術群の年齢, PS には偏りは認められない ものの, 多発転移例 7 例がすべて非手術群に属してい た。また，脳転移診断後の免疫療法としては，IFN- $\alpha$, IL-2ともに 9 例に施行されたが, 脳転移巣の手術を施 行せずに免疫療法を施行した症例はそれぞれ 6 例と 4 例であり，これらの症例で脳転移巣の縮小を認めた例 はなかった。また，脳転移巣術後の再発例 4 例はいず れも, 術後 IL-2療法を施行されていた。放射線療法は 20 例中 1 例に施行されたのみであった. 脳転移後 5 年 以上生存した症例は 2 例で, うち 1 例（症例18）は単 発性脳転移で脳以外の遠隔転移を認めない症例であ り, もう 1 例（症例19）は, 対側腎転移巣核出術後に 脳転移を認めたが，2例とも脳転移巣の手術を施行さ れていた。症例19は脳転移巣手術後約10年再発を認め ず，現在も外来通院中である。

\section{考察}

本研究においては, 全腎細胞癌患者の $6.5 \%$ に脳転移

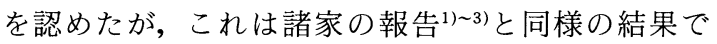
あった。

原発巣の患側の検討では，右側が脳転移を生じやす い傾向が認められたが，左側の方が多いという報告も ある3).われわれの検討では, 肺転移を生じた50例の原 発巣の患側は左24例, 右24例, 両側 2 例であり, 脳転 移が肺転移に引い続いて起こる可能性が高いことを考 慮すると, 患側による頻度の違いはないと考えるほう が妥当ではないかと考える.

病理学的所見では, high grade, high stage の症例 が多い傾向があるのみで，脳転移症例に特徵的な所見 は見い出せなかったが, 諸々の報告1)3でもみられるよ うに, pT2や grade 1の症例でも脳転移を生じる可能性 があるといえる.

脳転移発見の契機としては，他の報告 ${ }^{35) 56)}$ と同様に 麻痺が最も多かった。また，1例を除いて，脳転移に よる症状の出現により発見されている，肺，骨転移群 の脳転移合併率の高さを考慮すると，これらの症例に は年に 1 回位脳の CT スキャン, MRI などの画像検査 を施行すべきではないかと考える。

全国脳腫瘍統計 ${ }^{7)}$ による, 転移性脳腫瘍の $63.4 \%$ は単発性である．自験例でも20例中13例（65.0\%）が 単発性転移であった。長谷川ら ${ }^{8)}$ は, 転移性脳腫瘍が新 生血管を形成せず, 既存の血管を栄養血管として浸潤, 増殖し, 腫瘍周辺部では, 脳血液関門が保たれている ことを示しており，これが転移性脳腫瘍に単発性のも のが多い原因ではないかと思われる。

脳転移の診断時期については，8例が原発巣の診断 から 5 年以上経過して肺転移が出現しており, 肺や骨 への転移を生じつつ, 長い時間を経て脳転移を生じる 傾向が認められた，脳転移が肺転移や骨転移に合併し て起こる頻度が高い傾向にあるとの報告は多( ${ }^{1) ~ 3) . ~}$ 自験例においても，20例中肺転移を合併した症例が 17 例 $(85.0 \%)$ ，骨転移を合併した症例が10例（50.0\%） であり，肺転移症例 50 例中の $34.0 \%$, 骨転移症例 24 例 中の $41.7 \%$ を占めた。図 1, 図 3 からも明らかなよう に, 肺, 骨転移を合併した症例は, 長期間生存したと しても最終的に脳転移が出現しており，孤立性脳転移 が 2 例のみであることも考慮すると, 脳転移が多臓器 転移の一環として出現しやすいことが強く示唆され る.増田ら ${ }^{3)}$ はこの点について, 脳転移の転移経路の問 題を指摘している.脳にはリンパ管組織が存在せず, 
転移性脳腫崵の発生部位が中大脳動脈領域に多いこと から，脳転移が大循環系を経て血行性転移することが 示唆されるが, 腎細胞癌に限らず, 悪性腫瘍が脳へ転 移するためには, 脳血液関門を腫瘍細胞が通過するこ とが必要である。この通過機構については Warren ら ${ }^{9}$ の微小損傷仮説が有名だが, 詳細は明らかにされ ていない. 脳転移が多臓器転移の一環として出現しや すいことと, 肺, 骨転移症例群の脳転移合併頻度の高 さを考慮すると, 進行性腎細胞癌においては, 脳転移 を引き起こしやすい因子が関与している可能性もあ り, これらの究明が今後の課題であると思われる.

肺転移症例の脳転移の有無による予後への影響につ いては, 脳転移を合併した肺転移症例群の生存率と脳 転移を合併していない肺転移症例群のそれには, 有意 な差は得られなかった。これに関しては, 脳転移切除 例の治療成績が良好であることが大きく寄与している と思われる. 転移性脳腫瘍の死因の 4 分の 3 は脳転移 に起因しないとの報告 ${ }^{10)} も$ みられるが, 自験例では, 20 例中 7 例が脳転移出現後 6 力月以内に脳へルニアや癌 性髄膜炎などの脳転移による合併症によって死亡して おり, 適切な治療が施行されない限り, 脳転移症例の 予後は不良であると考えられる.

治療法と予後との関係では, 脳転移巣に手術を施行 した群は非手術群より予後良好である傾向がみられ た。この結果の背景には, 非手術群に多発性脳転移症 例が多く含まれたことが大きく関与していると考えら れ, 脳転移巣手術施行の有無がすなわち予後を左右す る重要な因子と結論できるわけではない. しかし, 手 術群の 1 年生存率は $88.9 \%, 5$ 年生存率は $33.3 \%$ と予 後の改善傾向が認められたことと, 症例18，19のよう に比較的 PS が悪くても脳転移巣手術後の長期生存例 が認められたことから, 転移巣が手術可能な部位に存 在する場合は, 積極的に脳転移巣の外科的切除を施行 することも治療法の選択の一つとして考慮すべきと考 える.

一方, 脳転移巣に対する免疫療法において, 脳転移 巣の縮小を認めた例はなく, 脳転移巣に対する免疫療 法の限界を示唆する結果となった。ささらに, 肺転移巣 に対するIL-2治療群は脳転移が出現しやすい傾向が 認められ, 脳転移再発例はいずれも術後に IL-2を投与 されていたＩL-2が脳転移を惹起しやすいことは諸及 の報告 ${ }^{11) 12}$ にもみられる. Ellison ら ${ }^{13)}$ は IL-2投与後の 細血管透過性の変化による脳血管関門の障害について 言及しており，IL-2治療により脳転移が惹起されやす
い可能性を示唆している，また，Fortis ら ${ }^{14)}$ は，進行 癌に対するIL-2治療により, 血中の intercellular adhesion molecule-1（ICAM-1）などの接着因子の濃 度が上昇することと血管内皮細胞の変化の関係につい て述べており,このことから, IL-2治療による脳転移に 接着因子が関わっている可能性も示唆され, 脳転移を 含めて, 進行腎癌の遠隔転移と接着因子などの関連に ついて基礎的研究の成果に期待がもたれる.

\section{結 語}

1. 腎細胞癌脳転移は, 全症例の $6.5 \%$, 肺転移例の $34.0 \%$, 骨転移例の $41.7 \%$ に認められ, 他藏器転移合 併傾向が認められた。

2. 原発巣の病理組織学的所見には特徵が認められ なかった。

3. 脳転移巣の外科的切除により, 予後の改善が得ら れる可能性が示唆された。

4. 脳転移巣に対する免疫療法には明らかな治療効 果は認めなかった。

5. 肺転移症例において, IL-2には脳転移出現を惹起 する可能性があることが示唆された。

\section{文献}

1）米瀬淳二, 川上 理, 上田朋宏, 続 真弘, 影山 進, 吉村耕治, 山内民男, 福井 旄, 河合恒雄: 腎 細胞癌脳転移の臨床的検討. 日泌尿会誌, 86,1287 $-1293,1995$.

2) Saito, H., Shimbo, T., Tasaka, T., Iida, T. and Hara, K. : Brain metastasis of renal adenocarcinoma. Tokai J. Exp. Clin. Med., 7, 337-343, 1988.

3）増田富士男, 荒川由和, 大西哲郎, 仲田浄治郎, 鈴 木正泰, 町田豊平: 腎細胞癌の脳転移. 日泌尿会 誌, 75, 278-282, 1984 .

4) 日本泌尿器科学会, 日本病理学会, 日本医学放射線 学会編: 泌尿器科・病理・放射線科. 腎癌取扱い規 約，第 2 版，金原出版，東京， 1992 .

5) Nisce, L.Z., Hilaris, B.S. and Chu, F.C.H.: A review of experience with irradiation of brain metastasis. Am. J. Roentogenol., 111, 329-333, 1971.

6）末山博男, 酒井郁夫, 北村達夫, 斎藤真理, 西原真 美子, 鈴木康夫, 稲越英機, 新妻伸二 : 転移性脑腫 瘍の放射線治療に関する検討. 臨放, 30, 579-586, 1985.

7）脳腫場全国統計委員会: 脳腫場全国集計調査報 告, 8, 47, 1993.

8) Hasegawa, H., Ushio, Y., Hayakawa, T., Yamada, K. and Mogami, H.: Changes of blood-brain barrier in experimental metastatic 
brain tumors. J. Neurosurg., 59, 304-310, 1983.

9) Warren, B.A.: Brain metastasis. p81-89, Martinus Nijhoff Publishers, 1980.

10）早川 徹, 吉峰俊樹, 有田憲生, 最上平太郎, 中川 秀光, 他：脳転移に対する局所的療法の進歩一特 に予後と手術適応に関して一. 癌と化学療法, 17 , 761-767, 1990.

11) Fujioka, T., Nomura, K., Hasegawa, M., Ishikura, K. and Kubo, T.: Combination of lympholine-activated killer cells and interleukin-2 in treating metastatic renal cell carcinoma. Brit. J. Urol., 73, 23-31, 1994.

12）中野悦次, 岩崎 明, 瀬口利信, 菅尾英木, 多田安 温, 松田 稔, 園田孝夫：進行性腎癌に対する Lymphokine-activated killer cell おょび interleukin-2 による併用療法の有用性ならびにそ の限界. 日泌尿会誌，82，395-404， 1991.

13) Ellison, M.D., Povishock, J.T. and Merchant, R. E.: Blood brain barrier dysfunction in cats following recombinant interleukin-2 infusion. Cancer Res., 47, 5765-5770, 1987.

14) Fortis, C., Galli, L., Consogno, G., Citterio, G., Matteucci, P., Scaglietti, U. and Bucci, E. : Serum levels of soluble cell adhesion molecules (ICAM-1, VCAM-1, E-selectin) and of cytokine TNF-alpha increase during interleukin-2 therapy. Clin. Immunol. Immunopathol., 76, 142147, 1995.

（1997年9月1日受付，1998年3月19日受理） 